\title{
Farklı Konumsal Çözünürlüğe Sahip Uydu Görüntüleri Kullanarak CORINE Arazi Örtüsü/Arazi Kullanım Sınıflarının Belirlenmesi
}

\author{
Nursaç Serda KAYA ${ }^{1}$, İnci DEMIRAĞ TURAN ${ }^{2 *}$, Orhan DENGIZZ ${ }^{1}$, Fikret SAYGIN ${ }^{3}$ \\ ${ }^{1}$ Ondokuz Mayls Üniversitesi, Ziraat Fakültesi, Toprak Bilimi ve Bitki Besleme Bölümü, Samsun, TÜRKIYE \\ ${ }^{2}$ Samsun Üniversitesi, İktisadi İdari ve Sosyal Bilimler Fakültesi, Coğrafya Bölümü, Samsun, TÜRKIYE \\ ${ }^{3}$ Karadeniz Tarımsal Araștırma Enstitüsü Müdürlüğü, Toprak ve Su Kaynakları Bölümü, Samsun, TÜRKİYE
}

\begin{abstract}
Geliş Tarihi/Received: $18.05 .2020 \quad$ Kabul Tarihi/Accepted: 30.06 .2020
ORCID ID (Yazar surasma göre / by author order)

(D) orcid.org/0000-0001-9814-5651 (Dorcid.org/0000-0002-5810-6591 (1Dorcid.org/0000-0002-0458-6016 (Dorcid.org/0000-0001-7771-806X

"Sorumlu Yazar/Corresponding Author: dmrginci@gmail.com
\end{abstract}

Öz: Arazi örtüsü/kullanımı sınıflarının mevcut konumsal dağılımlarının belirlenmesi ve süreç içerisinde meydana gelen değişimlerinin incelenmesi ekonomik ve sosyo-kültürel birçok alanda gerçekleştirilen çalışmalar için önemli bir temel oluşturmaktadır. Bu nedenle, arazi örtüsü/arazi kullanımı hakkındaki bilgilerin kendi içlerinde tutarlı olabilmesi için sistematik bir şekilde sınıflandırılması ve belli standartlarda üretilmesi gerekmektedir. Bu çalışma ile Samsun ili Vezirköprü (Türkiye) ilçesine ait 11251 hektar büyüklüğünde bir alanın ait Landsat 8, Sentinel 2 ve Triplesat uydu görüntülerinden CORINE arazi kullanım/arazi örtü sınıflamasının birinci ve ikinci düzeylerinde dağılım haritalarının oluşturulması ve yer gerçekleri ile karşılaştırmalarının yapılması amaçlanmıştır. Elde edilen sonuçlara göre, çalışma alanına ait tüm uydu görüntülerinde en yaygın dağııım gösteren sınıfın tarım alanları olduğu belirlenmiştir. Sınıflama hassaslığı bakımından Sentinel ve Triplesat uydu görüntülerine ait kappa değerleri (\% 92.95 ve \% 93.11) benzer hassasiyette oranlanırken, Landsat uydu görüntüsünde bu değerin \% 83'e düştüğü belirlenmiştir. Ayrıca yaklaşık 34 yıllık süreç içerisinde gerek tarım alanlarından gerekse de orman alanlarından bir kısmı yapay alanlara kaydığı belirlenmiștir. Çalıșma sonucu arazi örtüsü/kullanımının izlenmesinde elde edilen güvenilir sonuçlar ile uydu görüntülerinin geniş alanları, kısa zaman periyodlarında ve yüksek çözünürlüklü olarak gözlemleme kabiliyetlerinden faydalanılabileceği önerilmiştir.

Anahtar Kelimeler: CORINE sınıflandırması, uydu verileri, Samsun, mekansal dağılım, görüntü ișleme

\section{Determination of CORINE Land Cover/Land Use Classes Using Satellite Images with Different Spatial Resolution}

\begin{abstract}
Determining the current spatial distribution of land cover/use classes and examining the changes occurring in the process constitutes an important basis for studies conducted in many economic and socio-cultural areas. Therefore, for the information on land cover/land use to be consistent among themselves, it must be systematically classified and produced to certain standards. The aim of this study was aimed to produce distribution maps of the land use/land cover classes from Landsat 8, Sentinel 2, and Triplesat satellite images of an area of 11251 hectare in Samsun, Vezirköprü (Turkey) district and to compare them with the ground reality. According to the results obtained, it was determined that the most widely distributed class in all satellite images of the study area was the agricultural areas. In terms of classification accuracy, Kappa values $(92.95 \%$ and 93.11\%) of Sentinel and Triplesat satellite images were proportionally similar, while this value decreased to $83 \%$ in the Landsat satellite image. In addition, it has been determined that some of the agricultural and forest areas have shifted to artificial areas in a 34-year period. As a result of the study, it has been suggested that reliable results obtained in the monitoring of land cover/land use can benefit from the ability to observe large areas of satellite images in short periods and high resolution.
\end{abstract}

Keywords: CORINE, satellite imagery, Samsun, spatial distribution, image processing 


\section{Giriș}

Giderek artan ve 2050 yılında yaklaşı 10 milyara ulaşacağ1 öngörülen dünya nüfusunun beraberinde getirdiği aşırı mekânsal kullanım ve sanayileşme faaliyetleri, doğal kaynakların hızla tüketilmesine yol açmakta ve bunun bir sonucu olarak da insan ihtiyaçlarının giderilmesinde yetersiz kalınmaktadır. Tarımsal faaliyetlerden yerleşim alanlarına kadar çok geniş bir kullanım alanına sahip en değerli doğal kaynaklardan biri olan arazilerin bilinçsiz kullanımı sonucu potansiyelinin bozulmasına, verimsizleşmesine ve kirlenmesine yol açmaktadır (Öztürk ve ark., 2010; Gülersoy, 2014). Ayrıca, nüfustaki bu dramatik artış kentlerin çarpık ve düzensiz büyümesi ile tarım, orman ve mera alanları üzerine olan baskıların artmasına neden olmaktadır. $\mathrm{Bu}$ nedenle tarımsal arazi planlamasında etkin arazi kullanım politikalarını geliştirmek başta olmak üzere, gelecekteki talepleri de göz önünde bulundurarak farklı arazi varlığ 1 tanımını kapsayan tüm alanların uygun yerlere dağılımını sağlamak ve sürdürülebilir bir arazi yönetimi için güncel arazi örtüsü/ kullanım durumu hakkındaki bilgilere önemle ihtiyaç duyulmaktadır.

Arazi örtüsü ve arazi kullanımı terimleri çoğu zaman birlikte kullanılmaktadır. $\mathrm{Bu}$ yüzden bu terimlerin açık ve anlaşılır bir biçimde tanımlanması oldukça önem arz etmektedir. Arazi örtüsü; inşa alanları, ormanlar, tarımsal alanlar, sulak araziler, yarı-doğal alanlar ve su kaynakları gibi sınıflardan oluşan, dünyanın yüzeyini fiziksel ve biyolojik olarak kaplayan bir örtüdür. (Di Gregorio ve Jansen, 2000, Karnieli ve Rozenstein, 2011). Diğer taraftan arazi kullanımını ise; yerleşim, endüstri, ticaret, tarım, orman ve dinlence olarak karakterize edilmiş alanlar üzerindeki insan faaliyetleri olarak ifade edilmektedir.

Türkiye'de hızla artan nüfus ve sanayileşme faaliyetleriyle birlikte, arazi örtüsü/arazi kullanımında zamansal ve mekânsal anlamda dinamik bir şekilde çok hızlı değişiklik meydana gelmektedir. Tarımsal arazi kullanımında yaşanan değişim incelendiğinde, özellikle Cumhuriyetin kuruluşundan sonra, artan nüfusa paralel olarak tarıma açılan arazi miktarında yıllar itibarıyla önemli bir artışın gerçekleştiği görülmektedir. Bu anlamda 1928 yılında yaklaşık 6.6 milyon hektar alanda tarım yapılmakta iken, bu rakam 1950 yılında 25.3 milyon hektara, 1980'li y1lların sonunda yaklaşı 28 milyon hektar seviyelerine ulaşmıştır (Dengiz ve ark., 2019). Fakat Türkiye tarım arazilerinin toplam varlığı yaklaşık olarak 27.5 milyon ha ile tarım arazilerinin büyüklük olarak son noktasına geldiği bu tarihten sonra azalmalar meydana gelmekte olup, son yilların verilerine göre toplam 78 milyon hektar yüzölçümünün yaklaşık \% 31 'ine tekabül eden 23.9 milyon hektarlık k1smı tarım arazisi olarak değerlendirilmektedir (Anonim, 2020a). Günümüzde gelișen teknolojiyle birlikte üzerinde yaşadığımız coğrafya hakkında güncel ve doğru bilgilerin hılı bir şekilde elde edilmesi kolaylaşmıştır. Bunun için kullanılan en yaygın ve etkili yöntemler coğrafi bilgi sistem (CBS) ve uzaktan algılama (UA) teknikleridir (Özyazıcı ve ark., 2014). Bu tekniklerden özellikle birçok yer bilimi çalışmalarında gereksinim duyulan arazi örtüsü/arazi kullanımının tespitinin yanında zamansal ve mekânsal değişimlerinin gözlenmesinde de yaygın olarak faydalanılmaktadır. Nitekim Dengiz ve Demirağ Turan (2014), Samsun ili Atakum ilçesinde ASTER uydu görüntüleri kullanılarak 1984 yılında 24313.76 ha olan tarım arazisinin, 2011 y1lında 6960.69 hektara gerilemiş olduğunu, buna karşı11k tarım dışı arazi büyüklüğünün ise 1893.36 hektardan 7917.73 hektara yükseldiğini belirlemişlerdir. Yeryüzü üzerinde dağılım gösteren arazi örtüsü/arazi kullanımı sınıflarının ve bu sınıfların mekânsal dağılımlarının güncel durumlarının belirlenmesi ve zaman içerisinde meydana gelen değişimlerin incelenmesi; ekonomik, ekolojik, sosyal, askeri ve daha birçok alanda gerçekleştirilen çalışmalar için önemli bir temel oluşturmaktadır (Sertel ve ark., 2018). Bu nedenle, arazi örtüsü/arazi kullanımı hakkındaki bilgilerin kendi içlerinde tutarlı olabilmesi için standart ve sistematik bir şekilde sınıflandırılmasına ihtiyaç duyulduğu gibi belirli standartlara uygun olarak üretilmesi gerekmektedir. Bu amaç için 1985 yılında Avrupa Birliği Komisyonu tarafından başlatılmış olan CORINE (Coordination of Information on the Environment Project) en uygun sinıflandirma sistemlerinden biri olup; bu projeyle uydu görüntüleri üzerinden arazilerin izlenmesine yönelik arazi örtüsü/arazi kullanımındaki değişiklikler, uzaktan algılama ve coğrafi bilgi sistemleri yardımıyla tespit edilebilmektedir. Türkiye'de de arazi kullanım sınıflandırma haritalarının oluşturulması, arazi örtüsü /arazi kullanımın belirlenmesi ve arazi kullanımındaki zamansal değişimlerin CORINE düzeyinde incelenmesi gibi birçok çalışma yapılmıştır (Demirbüken, 1996; Eryılmaz, 2000; Everest ve ark., 2011; Gençer, 2011; Şimşek, 2017; Bulut ve ark., 2018; Kaya, 2019; Keleş ve Durduran, 2019; Öztürk ve Gündüz, 2019). Bulut ve ark. (2018) tarafindan İzmir'e ait meteorolojik radar verileri kullanarak CORINE Düzey 1 seviyesinde arazi örtüsü sinıfları yapay bölgeler (konut, endüstri bölgeleri vb.), tarımsal alanlar, ormanlar, sulak alanlar ve su kütleleri olarak belirlenmiş, elde edilen sonuçların arazi kullanımı ve planlama süreçlerindeki karar destek sistemlerine katkı 
sağlayacağı bildirilmiştir. Öztürk ve Gündüz (2019) tarafından Samsun ilinin arazi kullanımı/arazi örtüsündeki mekânsal ve zamansal değișimler 1990 ve 2012 yılları için CORINE düzey 2 seviyesinde sınıflandırılmış ve süreç içerisindeki antropojenik etkilerin çevresel sonuçlarının izlenmesi ve değerlendirilmesi açısından mekânsal CBS analizlerinin önemli bilgiler sunduğu rapor edilmiştir.

Benzer şekilde, Keleş ve Durduran (2019), 1995 y1lı LANDSAT-5 TM ve 2017 yıllı LANDSAT-8 OLI/TIRS uydu görüntülerinde piksel tabanlı kontrollü sınıflandırma tekniğini uygulayarak Osmaniye ilinin idari açıdan il olduktan sonraki süreçte yaşadıği değişimin arazi örtüsü/arazi kullanımına yansımasını CORINE Düzey 1 seviyesinde incelemişler ve bu süreçte hem nüfus artışı hem de yeni imar alanlarının açılması ile "yapay yüzeyler" sınıfında artış olduğunu gözlemlemişlerdir.

Arazi örtüsü/arazi kullanımındaki sınıflandırmaya yönelik diğer bir sistematik yaklaşım ise Amerika Birleşik Devletleri Jeoloji Servisi (USGS, United States Geological Survey) tarafından geliştirilmiş yöntem olup, Hassan ve ark. (2016) tarafindan Pakistan'ın Islamabad kentinde USGS'den 1992-2012 yılları arasında arazi örtüsü/kullanımındaki mekânsal ve zamansal değişimi LANDSAT uydu görüntüleri ile izlenmiş ve tarım, inşaat alanları ve su kütlelerinde artışlar olduğu bildirilmiştir. Ketema ve ark. (2020) tarafından Afrika'nın güneydoğusunda küçük toprak sahibi çiftçilerin yönettiği tarım arazilerinde arazi örtüsü/arazi kullanımında meydana gelen son 30 yıldaki değişim LANDSAT uydu görüntülerinde, coğrafi bilgi sistemi ile entegre edilen görüntü işleme algoritmaları kullanılarak izlenmiş ve kontrolsüz bir şekilde artan nüfus ile ekili alanlar genişleyerek, çıplak arazilerin arttığı ve bitki örtüsünün de azaldığı rapor edilmiştir.

$\mathrm{Bu}$ çalışmada, Samsun ili Vezirköprü ilçe sınırları içerisinde 20 mahallenin tamamını içeren arazilerde üç farklı mekânsal çözünürlüğe sahip uygu görüntülerinin (LANDSAT-8 $30 \mathrm{~m}$, SENTINEL 2B-15 $\mathrm{m}$ ve TRIPLESAT-0.8 m) eğitimli sinıflandırma yöntemi kullanılarak CORINE arazi örtüsü/arazi kullanımın sinıflandırma sisteminin 1 . ve 2 . seviyelerine göre haritaları oluşturmak ve sonuçların karşılaştırılmaları amaçlanmıştır.

\section{Materyal ve Yöntem}

\subsection{Araştırma alanının genel özellikleri}

Çalışma alanı Karadeniz Bölgesi’nin Orta Karadeniz Bölümü'nde yer alan Samsun ilinin Vezirköprü ilçesi sınırları içerisinde bir mikro havzadır. İlçeyi batıdan Saraydüzü ve Osmancık, doğudan Havza, güneyden Gümüşhacıköy ve Merzifon ilçeleri çevrelerken, kuzeyinde Durağan, Alaçam ve Bafra ilçeleri yer almakta olup, $41^{\circ} 02^{\prime}$ $27^{\prime \prime}-41^{\circ} 10^{\prime} 04^{\prime \prime}$ kuzey enlemleri ile $35^{\circ} 29^{\prime} 36^{\prime \prime}$ $35^{\circ} 37^{\prime}$ 04" doğu boylamları arasındadır (Şekil 1). Toplam çalışma alanı 11251 ha olup, ortalama deniz seviyesinden yüksekliği $243 \mathrm{~m}$ ile $744 \mathrm{~m}$ arasında değişmektedir. İlçenin Güneydoğu sınırında kalan çalışma alanı, Ağcaalan, Aydoğdu, Bahçekonak, Bayramköy, Boğazkoru, Çakırtaş, Çalköy, Çekmeden, Esenyurt, Güder, Kızılcaören, Kületek, Meşeli, Pazarc1, Tekekıranı, Yağc1, Yeniçelik, Yürükçal köylerini içerisine almaktadır.

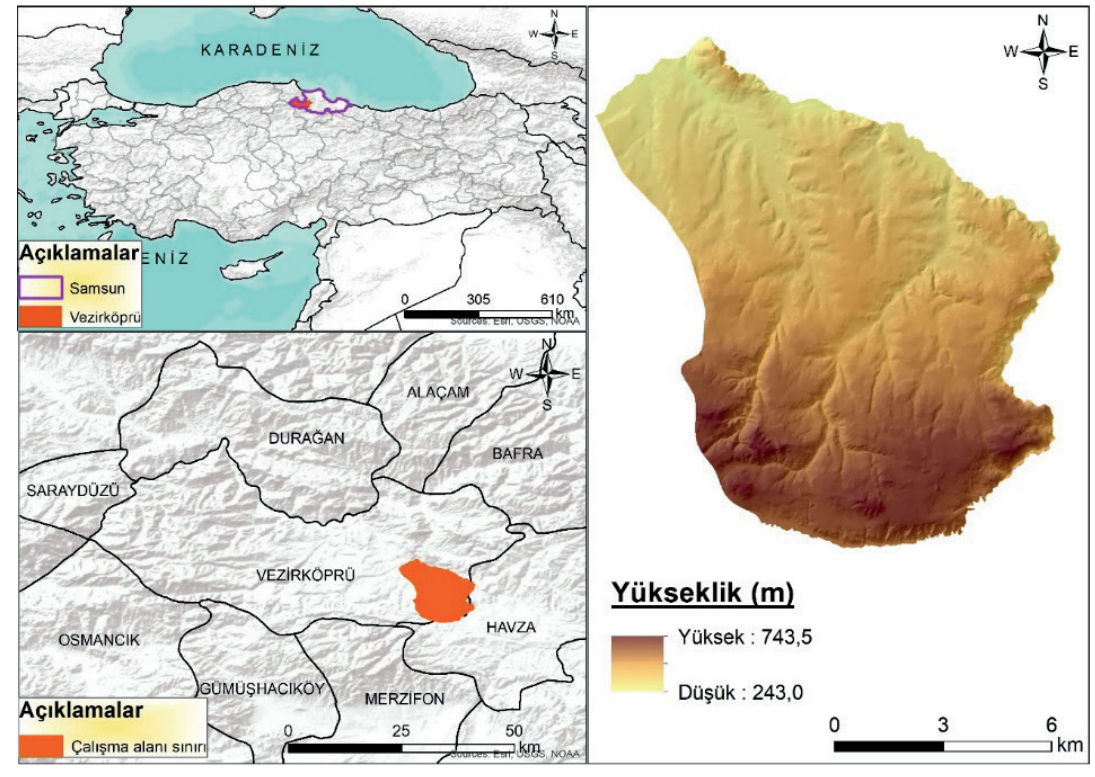

Şekil 1. Çalışma alanı yer bildiri haritası 
Vezirköprü iklim koşulları bakımından kıyı kuşağının nemli ılıman iklim tipi ile iç kesimlerin karasal iklim tipi arasında, geçiş kuşağının kendine özgü termik ve nemlilik özellikleriyle ayrılmakta; kışları kıyıya göre daha soğuk, yazlarda daha sıcak geçmektedir (Ağustos ayı aylık ortalama sicaklık $22.3{ }^{\circ} \mathrm{C}$ ) (Anonim, 2020b). Uzun yillık ortalamalara göre yıllık yağış miktarı 500 mm'nin üzerinde bulunmakta, çevresindeki yüksek kesimlerde yağış artışıyla birlikte kar şeklinde yağışların da etkili olduğu görülmektedir. Vezirköprü ilçe sınırları içerisinde dağ 1 lım gösteren toprakların jNSM 1.6.0 - Java Newhall Simülasyon Modeli (Van Wambeke ve ark., 1986, 1992; Newhall ve Berdanier, 1996; Van Wambeke, 2000) yardımıyla toprak sicaklık (Şekil 2) ve nem (Şekil 3) belirlenmiştir. Belirlenen alanda toprak sicaklık rejimi Mesic, toprak nem rejimi ise Typic Xeric olarak bulunmuştur.

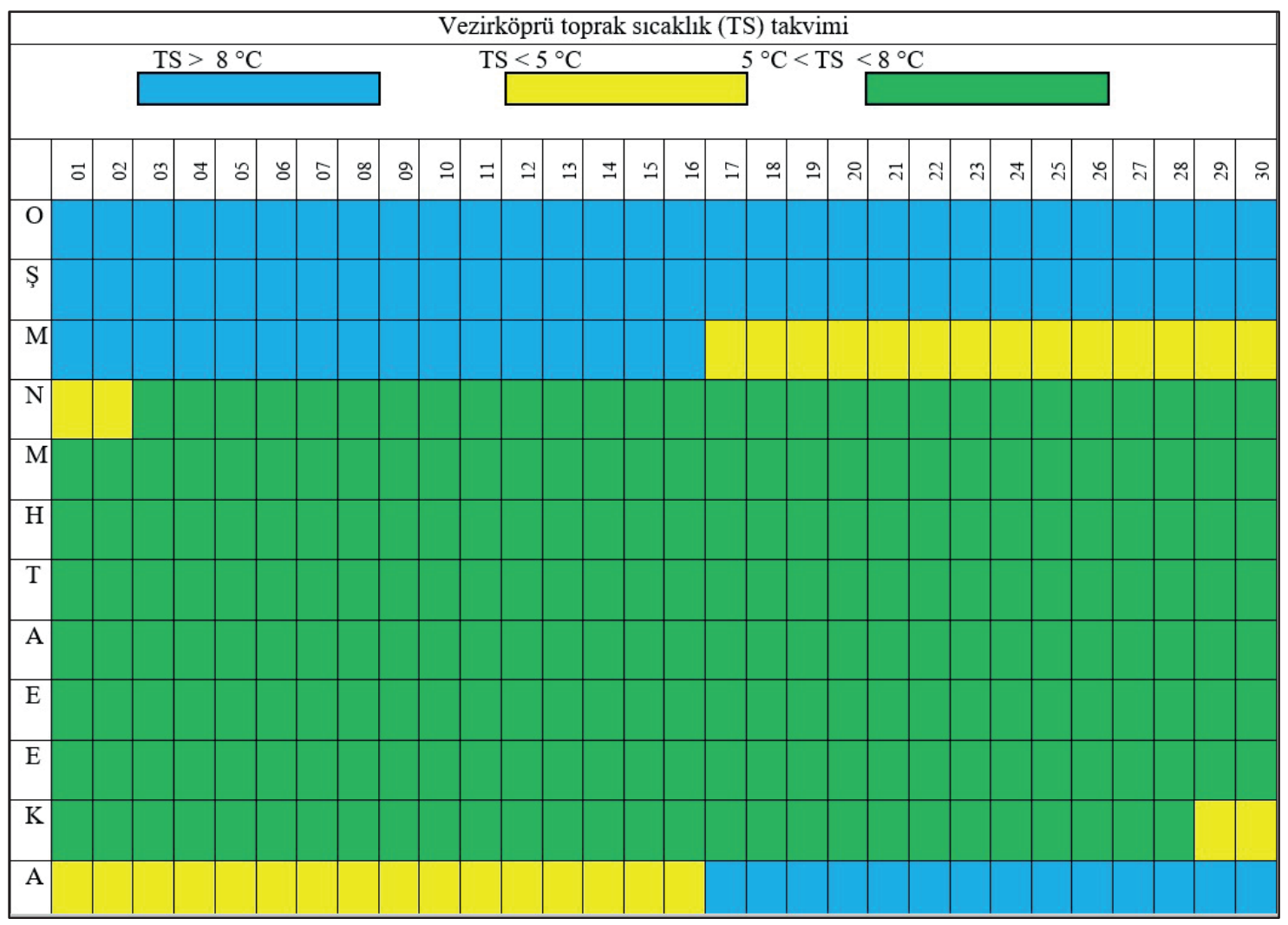

Şekil 2. Vezirköprü ilçesi Newhall modeline göre aylara göre toprak sıcaklık dağılımı
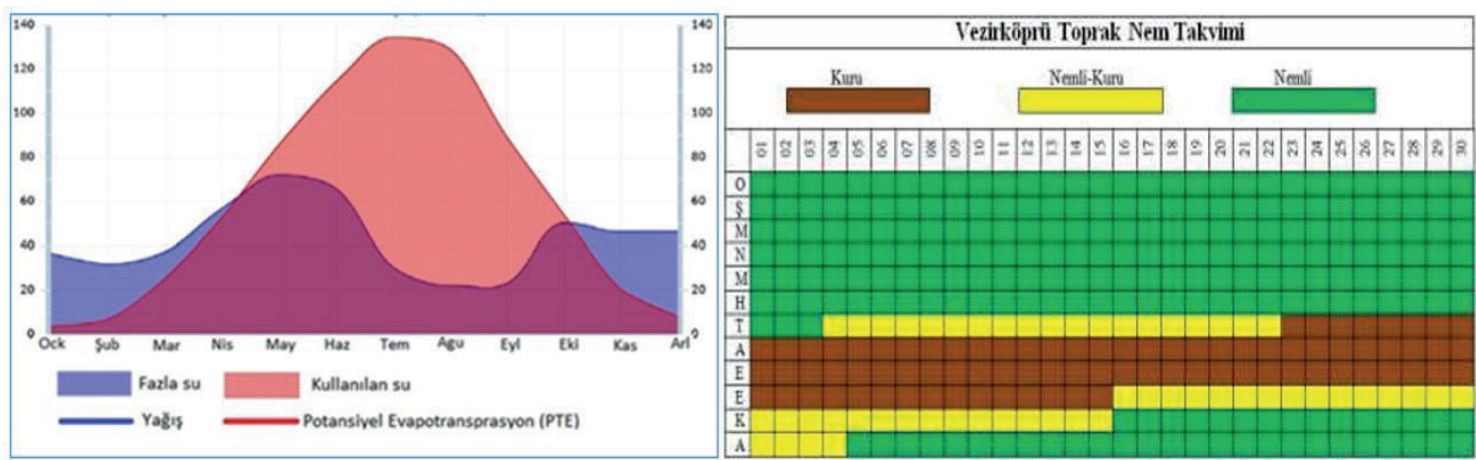

Şekil 3. Vezirköprü ilçesi Newhall modeline göre aylara göre toprak nem bütçesi dağılımı 


\subsection{Yöntem}

Çalışma alanına ait 04.06.2018 tarihli $80 \mathrm{~cm}$ çözünürlüğe sahip TRIPLESAT, 14.06.2018 tarihli 30 metre çözünürlüğe sahip LANDSAT-8 ve 03.06.2018 tarihli 15 metre çözünürlüğe sahip SENTINAL 2B uydu görüntüleri temin edilmiştir (Şekil 4). Uydu görüntülerinin sınıflandırmaya uygun hale getirilmesi için radyometrik, atmosferik ve geometrik düzeltme işlemleri yapılmış, kontrast arttırma ve keskinleştirme gibi görüntü zenginleştirme işlemleri uygulanmıştır. Görüntüler CORINE düzey 1 ve 2 ölçeğinde sınıflara ayrılmış ve buna göre sınıflandırma işlemi yapılmıştır.

CORINE düzey 1 sinıflamasında arazi çalışmalarında her bir sınıf için kontrolü sağlanan 100 referans noktası olmak üzere toplam 400 nokta kullanılarak sınıflandırma işlemi yapılmıştır.

Kontrollü sınıflandırma yönteminde çalışma alanındaki yeryüzü özelliklerini tanımlayan yeterli sayıdaki örnek alanlar kullanılarak her bir sınıf için spektral özellikleri tanımlı dosyalar oluşturulmuştur. Kontrollü sınıflandırmada en çok kullanılan sinıflandırma yöntemleri; En Kısa Mesafe (Minimum Distance), Mahalanobis Mesafesi (Mahalanobis Distance), En Yüksek Olasılık (Maximum Likelihood) ve Parametrik Kural (Parametric Rule) yöntemleridir. Ancak günümüzde en çok kabul gören yöntem En Yüksek Olasılık (Maximum Likelihood) yöntemidir (Ekercin, 2007). Bu-nedenle çalışma alanında sınıflandırmada En Yüksek Olasılık (Maximum Likelihood) yöntemi kullanılmıştır. Sınıflandırma ve doğruluk analizi işlemlerinde ENVI 5.3, haritalama işleminde ise ArcGIS 10.5 programları kullanılmıştır.

Çalışma sahasında sınıflandırılmış piksellerin doğruluk yüzdeleri hata matrisi yöntemi ile hesaplanmıştır. Hata matrisinde hata ölçüsü vardır. Bunlardan en çok kullanılanları; kullanıcı doğruluğu, üretici doğruluğu ve genel doğruluktur (Yan, 2006). Kullanıcı doğruluğu, Eşitlik 1'deki gibi hesaplanmıştır (Yan, 2006).

$$
\text { Kullanıcı Doğruluk }=\frac{n i i}{n \text { ik }}
$$

Burada $n_{\mathrm{ii}}$, sınıflandırılmış piksel ve $n_{\mathrm{ik}}$, sinıflandirılan toplam piksel anlamına gelmektedir.

Üretici doğruluğu ise her bir sınıf için doğru olarak sınıflandırılmış piksel sayısının, o sınıf için seçilen gerçek örtü tipi örnekleme sayısı toplamına (sütun toplamı) bölünmesiyle Eşitlik 2'deki gibi hesaplanmıştır.

$$
\text { Üretici Doğruluk }=\frac{n i i}{n k i}
$$

Burada $n_{i i}$, doğru olarak sınıflandırılmış piksel ve $n_{k i}$, o sınıf için seçilen gerçek örtü tipi örnekleme sayısı toplamı anlamına gelmektedir.

Eşitlik 1 ve 2'deki değerden biri 100'e yakınken diğeri çok düşükse ya da iki değer de çok küçükse seçilen eğitim alanlarının ya da kullanılan algoritmanın yeniden değerlendirilmesi gerekebilir (Boyac1, 2012).

Genel doğruluk, her bir sınıf için doğru olarak sınıflandırılmış piksel sayısının, toplam referans piksel sayısına bölünmesi ile Eşitlik 3 'teki şekilde hesaplanmıştır.

$$
\text { Doğruluk Yüzdesi }=\frac{\sum_{k=1}^{q} n_{k k}}{n} \times 100
$$

Elde edilen sonucun, toplam doğruluk oranının $\% 80$ ve üzerinde olması sinıflandırılmanın doğru ve güvenilir olduğunu göstermektedir (Koç ve Yener, 2001; Özdemir ve Özkan, 2003).
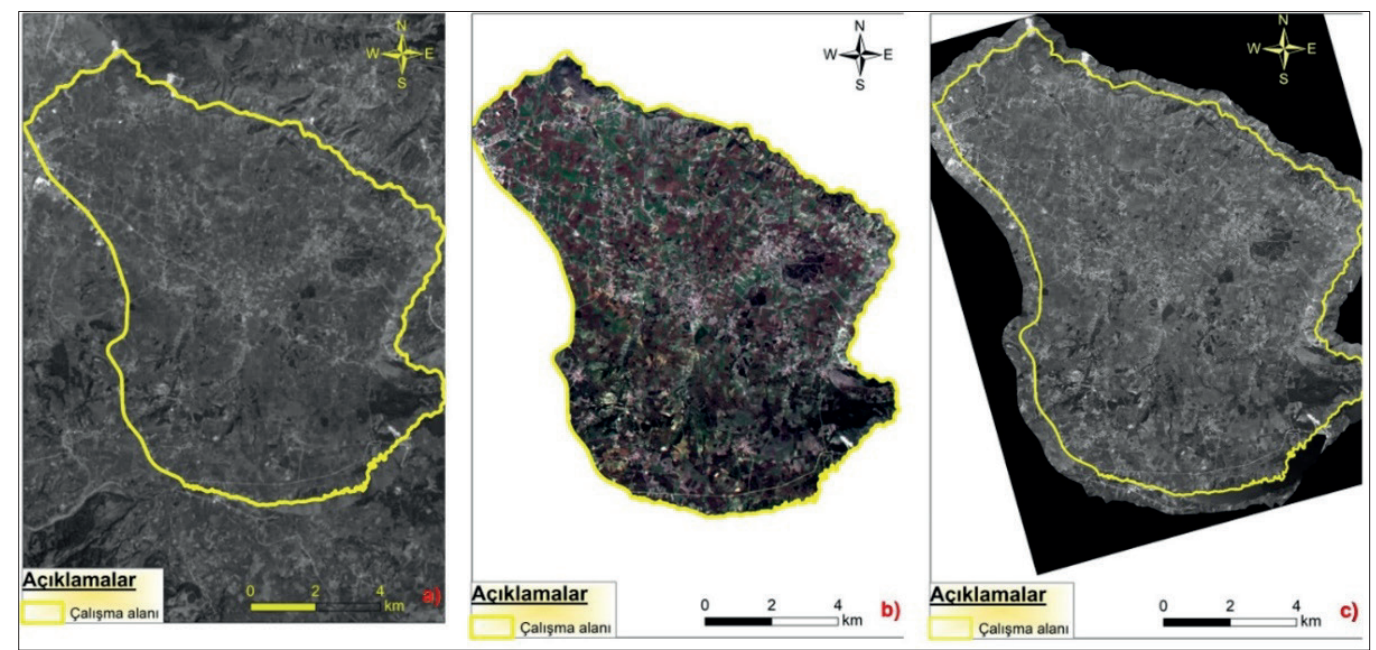

Şekil 4. Çalışma alanına ait a) Landsat 8 , b) Sentinel 2, c) Triplesat uydu görüntüleri 
Doğruluk değerlendirilmelerinde kullanılan diğer bir ölçüt kappa $(k)$ değeridir. Kappa (k) doğruluk değeri Eşitlik 4'te verilen formül yardımıyla hesaplanmıştır.

$$
K_{\text {hat }}=\frac{N \sum_{i=1}^{R} X_{i i}-\sum_{i-1}^{r}\left(X_{i+} * X_{+i}\right)}{N^{2}-\sum_{i=1}^{r}\left(X_{i+} * X_{+i}\right)}
$$

Eşitlik 4'te $r$, hata matrisindeki toplam satır sayısını; $\mathrm{X}_{i i}$, i. satır ve sütundaki piksel sayısını; $\mathrm{X}_{i}$, i. satırdaki toplam piksel sayısını; N, matrisin tamamındaki piksel sayısını ifade etmektedir.

Kappa değeri 0 ile 1 arasında bir değer alır. Bu değerin 1'e yakın olması doğruluğu daha güvenilir hale getirir (Lillesand ve ark., 2007). Gözlemciler arası uyumu belirten $\mathrm{k}$ değeri aralıkları şöyledir: $k$ : $\leq 0.20$ ise önemsiz uyum, $k: 0.21-0.40$ ise minimal uyum, $k$ : 0.41-0.60 ise orta derecede uyum, $k$ : 0.61-
0.80 ise önemli derecede uyum, $k$ : $0.81-1.00$ ise gözlemciler arasındaki uyumun tam olduğunu göstermektedir (Çelik, 2006).

CORINE sinıflandırma sistemi: 1985 y1lında Avrupa Birliği Komisyonu tarafından başlatılmış olan CORINE Projesi, sistematik bir veri tabanı oluşturulmasını hedefleyen bir Arazi Kullanımı Sinıflandirma Sistemi'dir (Anonim, 2020c). CORINE projesinde arazi örtüsü/arazi kullanımını ve değişimlerini belirlemek amacıyla arazi etütleri, hava fotoğrafları ve uydu verilerinden temel kartografik materyal olarak faydalanılmaktadır. Corine projesi, 2017 itibariyle aralarında Türkiye'nin de bulunduğu 39 ülkeyi kapsamaktadır. Tüm Avrupa' da kabul görmüş ve ülkemizde de UA ve CBS tekniklerinden faydalanılan CORINE Arazi Örtüsü Sınıflandırma Sistemi, 3 düzey içermekte olup bu çalışmada 1 . ve 2 . seviye tanımlar referans alınmıştır. Uydu görüntülerinde CORINE 1. ve 2. seviyelerine göre kategorize edilecek sinıf dağ 1 lımları Tablo 1'de verilmiştir.

Tablo 1. CORINE sisteminin 1. ve 2. düzey arazi kullanım/örtü türü sınıfları

\begin{tabular}{|c|c|}
\hline 1. Düzey & 2. Düzey \\
\hline \multirow{4}{*}{ 1-Yapay alanlar } & 1.1. Yerleşim alanları \\
\hline & 1.2. Endüstriyel, ticari ve ulaşım birimleri \\
\hline & 1.3. Maden, boşaltım ve inşaat alanları \\
\hline & 1.4. Yapay, tarımsal olmayan alanlar ${ }^{*}$ \\
\hline \multirow{4}{*}{ 2-Tarım alanları } & 2.1. Ekilebilir alanlar \\
\hline & 2.2. Sürekli ürünler ${ }^{*}$ \\
\hline & 2.3. Meralar \\
\hline & 2.4. Karışık tarımsal alanlar \\
\hline \multirow{3}{*}{ 3-Orman ve yarı doğal alanlar } & 3.1. Orman yerleri \\
\hline & 3.2. Maki ve otsu bitkiler (Fundalıklar) \\
\hline & 3.3. Bitki örtüsü az veya olmayan alanlar \\
\hline \multirow{2}{*}{ 4-Sulak alanlar } & 4.1. Karasal bataklıklar* \\
\hline & 4.2. Deniz kaynaklı bataklık alanlar* \\
\hline \multirow{2}{*}{ 5-Su kütlesi } & 5.1. Karasal sular \\
\hline & 5.2. Deniz sular1 ${ }^{*}$ \\
\hline
\end{tabular}

Belirtilen arazi kullanım türlerinden düzey 1 için tarımsal alanlar, yapay bölgeler, su kütlesi ve orman ve yarı doğal alanlar, düzey 2 için ise, yapay alanlar; yerleşim alanları, endüstriyel, ticari ve ulaşım birimleri, maden, boşaltım ve inşaat alanları, tarım alanları; ekilebilir alanlar, meralar, karışık tarımsal alanlar; orman ve yarım doğal alanlar orman yerleri; maki ve otsu bitkiler, bitki örtüsü olmayan veya az olan alanlar; su kütlesi, karasal sular olarak sınıflandırılmıştır.

Belirlenen sınıfların kontrolü için çalıșma alanı içerisinde doğruluk analizini gerçekleştirmek amacıyla her bir sınıfa ait 100 adet olmak üzere toplam 400 referans nokta seçilmiş ve el GPS'i ile koordinatları kaydedilmiştir.

\section{Bulgular ve Tartıșma}

\subsection{Analiz sonuçları}

Çalışmada, Samsun ili Vezirköprü ilçe sınırlarını kapsayan ve 2018 Haziran ayına ait Sentinel 2, Landsat 8 ve Triplesat uydu görüntülerinde uzaktan algılama ve coğrafi bilgi sistemi teknikleri kullanılarak arazi kullanım haritaları CORINE 1 . ve 2 . seviyeye göre üretilmiştir.

Uydu görüntülerinin CORINE 1. düzeye göre sinıflandirılması sonucu elde edilen alansal ve oransal dağılımlar Tablo 2'de ve dağılım haritaları Şekil 5'te sunulmuştur. Triplesat uydu görüntüsünde tarım alanları 9922 ha ile toplam 
Tablo 2. Landsat 8, Sentinel 2 ve Triplesat uydu görüntülerinin CORINE 1. düzey sinıflarına göre arazi kullanımı/arazi örtüsü alansal dağılımları

\begin{tabular}{lcccccc}
\hline \multirow{2}{*}{ Arazi kullanımı } & \multicolumn{2}{c}{ Landsat 8 } & \multicolumn{2}{c}{ Sentinal 2 } & \multicolumn{2}{c}{ Triplesat } \\
\cline { 2 - 7 } & Alan (ha) & Oran (\%) & Alan (ha) & Oran (\%) & Alan (ha) & Oran (\%) \\
\hline Orman ve yarı doğal alanlar & 1168 & 10.4 & 973 & 8.6 & 830 & 7.4 \\
Su yapılar1 & 12 & 0.1 & 12 & 0.1 & 12 & 0.1 \\
Tarımsal alanlar & 8376 & 74.4 & 9685 & 86.1 & 9822 & 87.3 \\
Yapay bölgeler & 1695 & 15.1 & 581 & 5.2 & 587 & 5.2 \\
\hline Toplam & 11251 & 100.0 & 11251 & 100.0 & 11251 & 100.0 \\
\hline
\end{tabular}

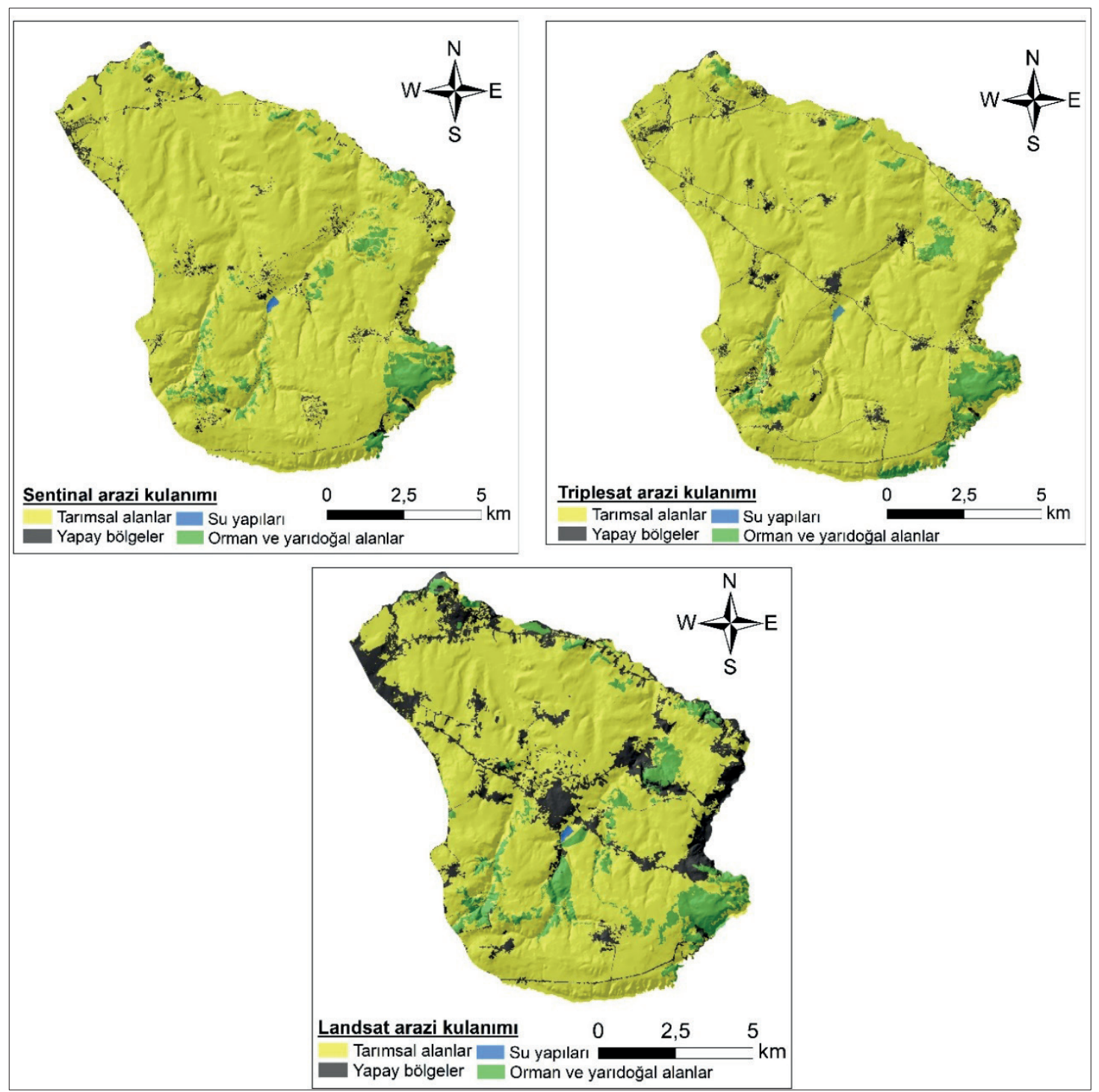

Şekil 5. Sentinel 2, Triplesat ve Landsat 8 uydu görüntülerinin CORINE 1. düzeye göre sınıflandırılmış arazi kullanımı/arazi örtüsü dağılım haritaları

sahanın \% 88.2'sini kaplayarak, çalışma sahasının en yaygın arazi kullanım türü olarak belirlenmiştir. Tarım alanlarını sırasıyla; orman ve yarı doğal alanlar (830 ha), yapay bölgeler (487 ha) ve su yapıları (12 ha) takip etmiştir. Sentinel 2 uydu görüntüsünün kontrollü sınıflandırma işlemi sonucu tarım alanlarının 9685 ha ile toplam alanın
\% 86.1'ini kapladığı belirlenmiştir. Triplesat ve Sentinel 2 uydu görüntülerinde benzer büyüklük dağılımı sergilediklerinden dolayı çalışma sahasının en yaygın arazi kullanım türü tarım alanları olarak belirlenmiştir. Triplesat uydu görüntüsünde tarım alanlarını sırasıyla; orman (973 ha), yapay bölgeler (581 ha) ve su kütlesi (12 ha) 
takip etmiştir. Çalışma alanda orman örtüsü dağınık bir yayılım göstermekte iken tarım alanlarının homojen bir şekilde dağılım gösterdiği görülmektedir. Landsat 8 uydu görüntüsünün kontrollü sinıflandırma sonuçlarına göre tarım alanları 8376 ha ile toplam sahanın \% 74.4'ini kaplayarak, çalışma sahasının yine en yaygın arazi kullanım türü olarak belirlenmiştir. Fakat Triplesat ve Sentinel 2 görüntüleri ile karşılaştırıldığında bu oran azalmış, yapay alanlar ise daha yüksek oranda sınıflandırılmıştır. Tarım alanlarını sırasıyla; yapay bölgeler (1695 ha), orman ve yarı doğal alanlar (1168 ha) ve su yapıları (12 ha) takip etmiştir. Landsat 8 uydu görüntüsünde tarım dışı olarak sinıflandırılan alanların diğer uydu görüntülerine göre daha fazla alan kapladığı görülmektedir. $\mathrm{Bu}$ durumun Landsat 8 uydu görüntüsünün çözünürlüğünün diğer iki uyduya göre daha düşük olmasından kaynaklandığı söylenebilir. Nitekim Sentinel 2 uydu görüntüsü piksel alan çözünürlüğünün daha hassas spektral ölçümler kaydedebilmesi sayesinde arazi örtüsünü Landsat 8 verilerine göre \% 4-\% 5 oranlarında daha doğru sınıflayabildiği bildirilmiştir (Forkuor ve ark., 2018).

Çalışma alanına ait uydu görüntülerinin CORINE 2. düzey sinıflandırması sonucu alansal ve oransal dağılımlar Tablo 3'te ve dağılım haritaları Şekil 6'da verilmiştir. Buna göre Landsat 8 uydu görüntüsü için CORINE 2. düzey sınıflandırmada \% 64.8'i ekilebilir alan-olarak belirlenmiş olup, çalışma alanının büyük bir bölümünü bu sınıfın kapladığı görülmektedir. Alanın 956 hektarlık (\% 8.5) kısmını şehir yapısı ve 340 ha (\% 3) ise endüstriyel, ticari ve ulaşım birimleri oluşturmaktadır (Şekil 6, Tablo 3).

Sentinel 2 uydu görüntüsü için CORINE 2. düzey sınıflamasına göre de çalışma alanının büyük bir kısmını ekilebilir tarım alanları (7871 ha / \% 70.0) oluşturmaktadır (Tablo 3). Fakat Sentinel 2 uydu görüntüsünde belirlenen alansal dağılımların Landsat8'e göre yüksek ( $\%$ 5.2) olduğu belirlenmiştir. Bitki örtüsü az veya olmayan bölgeler alanın \% 3.1'lik kısmını kaplamaktadır ve Landsat uydusuna göre daha belirgin bir şekilde ortaya çıkmıştır (Şekil 6). Ayrıca bu uydu görüntüsünde alanın \% $\quad 0.2$ 'lik kısmını maden ocakları, boşaltım ve inşaat sahaları ve karasal sular oluşturmaktadır. Maden ocakları, boşaltım ve inşaat sahalarının çalışma alanının kuzeyinde bulunan fundalık alanlarda ve güneydeki orman alanı çevresinde olduğu görülmektedir. Triplesat uydu görüntüsü için yapılan sınıflandırmada ise çalışma alanının büyük bir kısmının ekilebilir alanlar (\% 70.1) oluşturmakta ve hemen hemen Sentinel 2 uydu görüntüsündeki oranla paralellik göstermektedir. Fakat bu sınıflandırmada çalışma alanındaki endüstriyel, ticari ve ulaşım birimleri sınıfı alanın genelinde daha belirgin bir şekilde ortaya çıkmıştır (Şekil 6). Bu da Triplesat uydu görüntüsünün çözünürlüğünün diğer iki uyduya göre daha yüksek olmasından kaynaklanmaktadır.

Arazi örtüsü/kullanımlarının belirlenmesine yönelik çalışmalar Türkiye'de ilk olarak (Mülga) Köy Hizmetleri Genel Müdürlüğü tarafından yapılmıştır. 1987 yılında tamamlanan bu çalışmalarda göre arazi örtüsü/kullanımına ayrılmış olan sınıflamalar detaylı olmayıp, ana başlıklar halinde verilmiştir. Bu kullanımlar kuru tarım, sulu tarım, bağ-bahçe, fistık-zeytin-çay-kestane vb., çayır, otlak, orman, çalı-funda, yerleşim, sazlıkbataklık, ırmak yatakları, kıyı kumulları, çıplak kayalıklar ve su yüzeyleri olmak üzere 14 kullanım türüne ayrılmıştır (Anonim, 1987). Çalışma alanın Köy Hizmetleri Genel Müdürlüğü tarafından yapılan sinıflamaya göre Samsun il arazi varlığg1 raporuna göre (Anonim, 1984) arazi örtüsü/ arazi kullanımı dağılımında Ormanlık ve fundalık alanlar toplam alanın \% 11.1'i kaplarken, tarım alanları toplam alanın \% 88.8'ni kapladığı rapor edilmiştir. CORINE 1. düzeyde yüksek çözünürlüklü ve

Tablo 3. Landsat 8, Sentinel 2 ve Triplesat uydu görüntülerinin CORINE 2. düzey sinıflarına göre arazi kullanımı/ örtüsü alansal dağılımları

\begin{tabular}{|c|c|c|c|c|c|c|}
\hline \multirow[b]{2}{*}{ Arazi kullanımı } & \multicolumn{2}{|c|}{ Landsat } & \multicolumn{2}{|c|}{ Sentinal } & \multicolumn{2}{|c|}{ Triplesat } \\
\hline & $\begin{array}{l}\text { Alan } \\
\text { (ha) }\end{array}$ & $\begin{array}{c}\text { Oran } \\
(\%)\end{array}$ & $\begin{array}{l}\text { Alan } \\
\text { (ha) }\end{array}$ & $\begin{array}{c}\text { Oran } \\
(\%)\end{array}$ & $\begin{array}{l}\text { Alan } \\
\text { (ha) }\end{array}$ & $\begin{array}{c}\text { Oran } \\
(\%)\end{array}$ \\
\hline Bitki örtüsü az veya olmayan alanlar & 217 & 1.9 & 345 & 3.1 & 349 & 3.1 \\
\hline Ekilebilir alanlar & 7691 & 68.4 & 7871 & 70.0 & 7882 & 70.1 \\
\hline Karışık tarımsal alanlar & 965 & 8.6 & 1323 & 11.8 & 1214 & 10.8 \\
\hline Maden ocakları, boşaltım ve inşaat sahaları & 9 & 0.1 & 12 & 0.1 & 12 & 0.1 \\
\hline Maki veya otsu bitkiler (Fundalıklar) & 281 & 2.5 & 465 & 4.1 & 452 & 4.0 \\
\hline Endüstriyel, ticari ve ulaşım birimleri & 340 & 3.0 & 62 & 0.6 & 85 & 0.8 \\
\hline Meralar & 232 & 2.1 & 242 & 2.2 & 235 & 2.1 \\
\hline Orman yerleri & 548 & 4.9 & 578 & 5.1 & 571 & 5.1 \\
\hline Şehir yapıs1 & 956 & 8.5 & 341 & 3.0 & 439 & 3.9 \\
\hline Karasal sular & 12 & 0.1 & 12 & 0.1 & 12 & 0.1 \\
\hline Toplam & 11251 & 100.0 & 11251 & 100.0 & 11251 & 100.0 \\
\hline
\end{tabular}




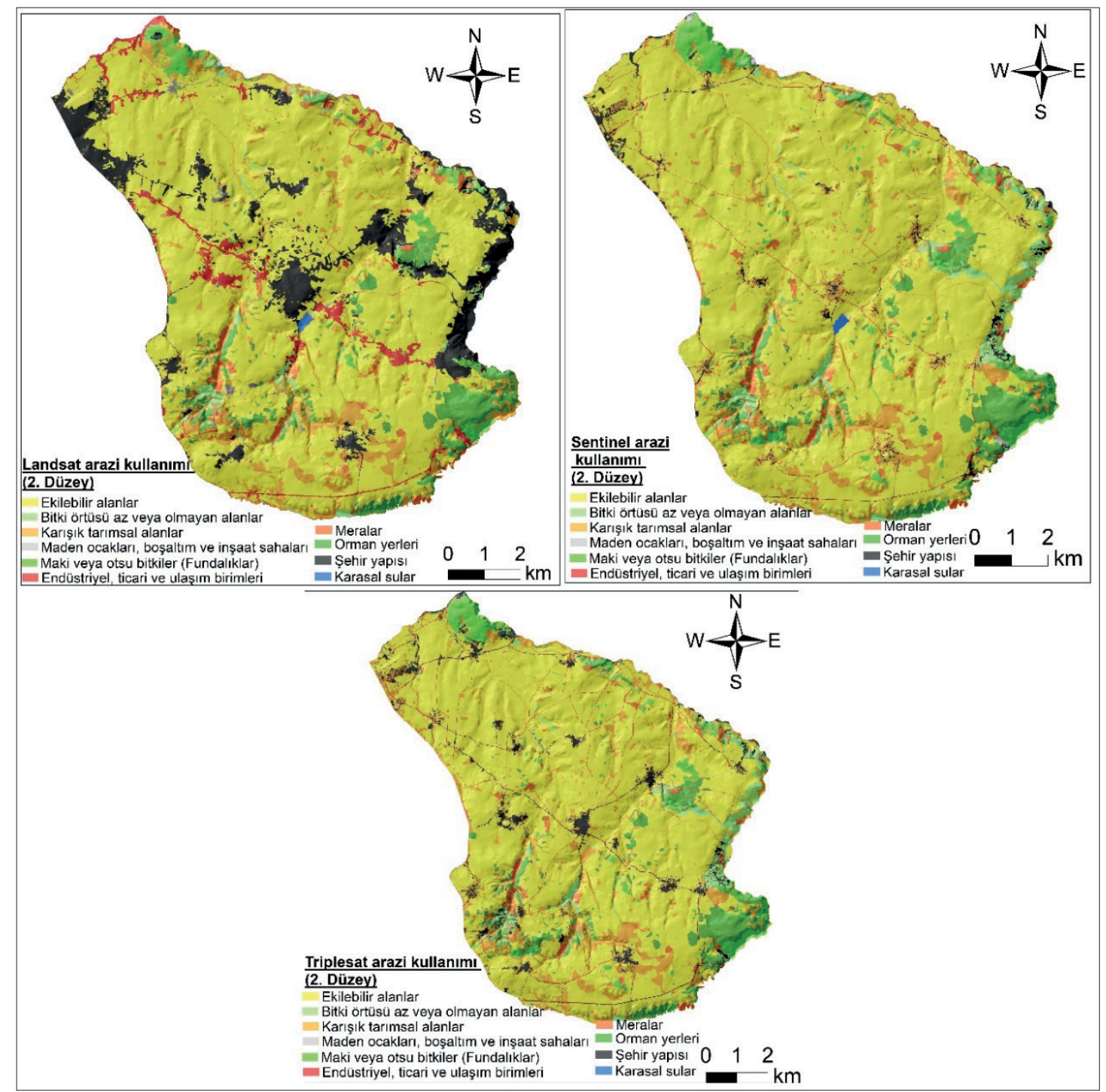

Şekil 6. Sentinel 2, Landsat 8 ve Triplesat uydu görüntülerinin CORINE 2. düzeye göre sınıflandırılmış arazi kullanımı/arazi örtüsü dağılım haritaları

yüksek doğruluk değeri elde edilen Triplesat verileri ile karşılaştırıldığında geçen otuz dört yıllık süreç içerisinde orman ve yarı doğal alanlar \% 7.4 tarım alanları ise \% 87.3'e gerilemiş olduğu belirlenmiştir. Bu alanların özellikle yapay alanlara doğru kaydığ 1 gözlemlenmiştir. Dengiz ve Sarığlu (2011) yaptıkları çalışmada Samsun ilinin yaklaşık $9579 \mathrm{~km}^{2}$ olan toplam alanının sadece \% 14.7'lik (141112.8 ha) kısmının işlemeli tarıma uygun alanlar olduğunu belirlemişlerdir. Dengiz ve Demirağ Turan (2014) tarafindan Samsun Atakum ilçesinde yapılan 1984 yılında tarım dıșı alan bulunmaz iken, 2005 yilında 560.3 ha (\% 29.1) ve 2011 yılında 962.9 ha (\% 50) olduğu rapor edilmiş; aynı çalışmada II. sınıf tarım arazilerinde ise 1984 yılında tarım dıșı alan yine yok iken 2005 yılında 321.59 ha $(\%$ 47.8) ve 2011 yılında 536.56 ha (\%79.7) alanın olduğu tespit edilmiştir. Geçmişten günümüzü yürütülen arazi örtüsü/kullanım tespiti ve izlenmesi üzerine yapılan çalışmalar gün geçtikçe tarım arazileri üzerindeki baskı arttırdığını göstermektedir. Bunun önüne geçebilmek ve planlama yapabilmek için uygun arazi kullanımına yönelik sistematik çalışmaların gelişen UA ve CBS tekniklerinde de faydalanılarak yürütülmesinin önemi daha da artmaktadır.

\subsection{Doğruluk analizlerinin değerlendirmesi}

Üç farklı çözünürlüğe sahip uydu görüntüsü kullanılarak CORINE arazi kullanım/arazi örtüsü sınıflama çalışmasına yönelik doğruluk analizleri saha çalışmaları sonucu belirlenen yer gerçekleri ile karşılaştırılmıştır (Tablo 4). Elde edilen sonuçlara göre Sentinel 2 uydu görüntüsünde \% 92.95 doğruluk katsayısı ile çıkarımlar yapılmıştır. Bu değere göre sınıflandırmanın doğru ve güvenilir 
Tablo 4. Çalışma alanı yer gerçeklerine göre Sentinel 2, Landsat 8 ve Triplesat uydu görüntülerinin doğruluk analizi sonuçları

\begin{tabular}{|c|c|c|c|c|c|c|c|}
\hline \multicolumn{8}{|c|}{ Sentinal (\%) } \\
\hline Sinif & Orman & Su kütlesi & Tarım dişı & Tarım & Toplam & $\begin{array}{c}\text { Üretici } \\
\text { doğruluğu }\end{array}$ & $\begin{array}{l}\text { Kullanıcı } \\
\text { doğruluğu }\end{array}$ \\
\hline Orman & 88.36 & 0 & 8.17 & 3.17 & 27.71 & 88.36 & 91.10 \\
\hline Su kütlesi & 0 & 99.26 & 0 & 0 & 35.77 & 99.26 & 100.00 \\
\hline Tarım alanları & 11.64 & 0.01 & 91.18 & 9.52 & 28.62 & 91.18 & 85.53 \\
\hline Yapay bölgeler & 0 & 0.73 & 0.65 & 87.31 & 7.90 & 87.31 & 94.49 \\
\hline Toplam & 100.00 & 100.00 & 100.00 & 100.00 & 100.00 & & \\
\hline \multicolumn{8}{|c|}{ Genel doğruluk $=\% 92.95$, Kappa değeri $=0.90$} \\
\hline \multicolumn{8}{|c|}{ Landsat $(\%)$} \\
\hline Sinif & Orman & Su kütlesi & Tarım & $\begin{array}{l}\text { Yapay } \\
\text { alanlar }\end{array}$ & Toplam & $\begin{array}{c}\text { Üretici } \\
\text { doğruluğu }\end{array}$ & $\begin{array}{l}\text { Kullanıcı } \\
\text { doğruluğu }\end{array}$ \\
\hline Orman & 90.75 & 0 & 5.26 & 1.27 & 30.67 & 90.75 & 92.01 \\
\hline Su kütlesi & 0.04 & 94.80 & 4.24 & 0.41 & 5.34 & 94.80 & 65.47 \\
\hline Tarım alanları & 5.98 & 3.60 & 85.61 & 14.52 & 40.40 & 85.61 & 86.26 \\
\hline Yapay alanlar & 3.23 & 1.60 & 4.89 & 83.80 & 23.59 & 83.80 & 87.05 \\
\hline Toplam & 100.00 & 100.00 & 100.00 & 100.00 & 100.00 & & \\
\hline \multicolumn{8}{|c|}{ Genel doğruluk $=\% \quad 87.37$, Kappa değeri $=0.83$} \\
\hline \multicolumn{8}{|c|}{ Triplesat (\%) } \\
\hline Sinif & Orman & Su kütlesi & Tarım & $\begin{array}{l}\text { Yapay } \\
\text { alanlar }\end{array}$ & Toplam & $\begin{array}{c}\text { Üretici } \\
\text { doğruluğu }\end{array}$ & $\begin{array}{l}\text { Kullanıc1 } \\
\text { doğruluğu }\end{array}$ \\
\hline Orman & 87.38 & 0 & 8.01 & 1.23 & 24.22 & 87.38 & 91.10 \\
\hline Su kütlesi & 0 & 99.25 & 0.30 & 0.00 & 31.26 & 99.25 & 100.00 \\
\hline Tarım & 11.63 & 0.01 & 89.25 & 3.75 & 25.12 & 89.55 & 85.40 \\
\hline Yapay alanlar & 0.99 & 0.74 & 2.44 & 95.02 & 19.40 & 95.02 & 94.49 \\
\hline Toplam & 100.00 & 100.00 & 100.00 & 100.00 & 100.00 & & \\
\hline
\end{tabular}

olduğu kabul edilmektedir (Koç ve Yener, 2001; Özdemir ve Özkan, 2003). Ayrıca 0.90 kappa değeri gözlemciler arasındaki uyumun tam olduğunu göstermektedir. Görüntüdeki en yüksek kullanıcı doğruluğu \% 100 ile su kütlelerinden elde edilmiştir. Su kütlelerini sırasıyla; yapay bölgeler (\% 94.49) orman ve yarı doğal alanlar (\% 91.10) ve tarım alanları (\% 85.53) izlemiştir. Landsat 8 uydu görüntüsü sınıflandırma sonuçları için \% 87.37 doğruluğa ulaşılmış ve kapa değeri 0.83 ile gözlemciler arasındaki uyumun tam olduğunu göstermektedir. En yüksek kullanıcı doğruluğu \% 92.01 ile orman ve yarı doğal alanlardan elde edilmiştir. Orman alanlarını sırasıyla; yapay bölgeler (\% 87.05), tarım alanları (\% 86.26) ve su kütlesi ( $\%$ 65.47) izlemiştir. Genel sınıflama doğruluğu \% 93.11 ve duyarlılığ 0.90 olan Triplesat uydu görüntüsünde en yüksek kullanıcı doğruluğu \% 100 ile su kütlesinden elde edilmiştir. Su kütlesini sırasıyla; yapay bölgeler (\% 94.49), orman ve yarı doğal alanlar (\% 91.10) ve tarım alanları (\% 85.40) izlemiştir.

CORINE 2. düzey sinıflandırmada ise tespit edilen 10 sınıf için 20'şer referans noktası alınarak toplam 100 nokta kaydedilmiştir. Belirlenen noktaların kontrollü sinıflandırma doğruluğu Landsat 8 uydu görüntüsü için \% 86.70, Sentinel 2 uydu görüntüsü için \% 86.80 ve Triplesat uydu görüntüsü için ise \% 89.78 olarak bulunmuştur. CORINE 2. düzey sinıflandırmada da genel sonuçların doğru ve güvenilir olduğu kabul edilmektedir. Çalışma alanından yapılan siniflandırmalarda hem genel doğruluk hem de kappa değerinin en yüksek olduğu, Triplesat uydu görüntüsünün yüksek mekânsal çözünürlüğe sahip olmasından dolayı arazi örtüsü /kullanım tespitinde Sentiel 2 ve Landsat verilerine göre nispeten daha etkili ve güvenilir olduğu belirlenmiştir.

\section{Sonuçlar}

Bu çalışmada 11251 ha büyüklüğündeki Samsun ili Vezirköprü ilçe sınırlarına ait; Landsat 8, Sentinel 2 ve Triplesat uydu görüntüleri uzaktan algılama ve coğrafi bilgi sistemi teknikleri kullanılarak kontrollü olarak sınıflandırılmış ve her bir uydu görüntüsüne ait arazi kullanım türleri CORINE Sinıflandırma Sistemi'nin 1. ve 2. düzeylerine göre $\% 80$ ve üzerinde yüksek doğrulukla ayrılmıştır. Çalışma alanının CORINE 1. düzey arazi kullanımı/arazi örtüsü sınıflandırmasına göre üç uydu görüntüsünde de tarımsal alanlar büyük bir alan kaplamaktadır. Tarım alanları Landsat uydu görüntüsünde toplam alanın \% 74.4’ünü, Sentinal uydu görüntüsünde \% 86.1'ini ve Triplesat uydu görüntüsünde ise $\% \quad 87.3$ 'ü oluşturduğu görülmektedir. Tarım alanlarını orman ve yarı doğal 
alanlar takip etmektedir. Orman ve yarı doğal alanlar Landsat uydu görüntünde 1168 ha (\% 10.4), Sentinal uydusunda 973 ha ( $\%$ 8.6) ve Triplesat uydusunda ise 830 ha (\% 7.4) alana sahiptir.

CORINE 2. düzey arazi kullanımı/arazi örtüsü sinıflandırmasında da ekilebilir alanlar en fazla alan kaplamaktadır. Ekilebilir alan Landsat uydu görüntüsü sınıflandırmasında 7691 ha (\% 68.4), Sentinal uydu görüntüsünde 7871 ha $(\% 70.0)$ ve Triplesat uydu görüntüsünde ise 7882 ha (\% 70.1) alan kaplamaktadır. Yine her üç görüntüden yapılan sınıflandırmada da maden ocakları, boşalım ve inşaat alanı ve karasal sular en düşük alana sahip sınıf olmuştur.

Bütün uydu görüntülerinde doğruluk \% 80'in üzerinde çıkmıştır. Bu da sınıflandırmanın doğru ve güvenilir olduğunu göstermektedir. Bu durum arazi örtüsü / kullanımının belirlenmesi ve izlenmesinde yüksek çözünürlüklü uydu görüntülerinden faydalanılmasının güvenilir olduğunu göstermektedir. Ayrıca bütün uydu görüntüleri için yapılan sınıflandırmada kappa değerinin 0.81-1.00 arasında oranlanması ile gözlemciler arasındaki uyumun tam olduğu belirlenmiştir. Doğruluk analizinde her ne kadar üç uydu görüntüsünde de doğruluk dereceleri bilimsel olarak kabul edilebilir sinırlar üzerinde olsa da Sentinel 2 ve Triplesat uydu görüntüleri birbirine yakın sonuçlar göstermiş ve daha yüksek değerler elde edilerek sınıflama daha hassas hale getirilmiştir.

Günümüz teknolojilerinin kullanılmasıyla kısa sürede çok daha fazla bilgi kullanılabilir ve işlenebilir hale gelmektedir. Özellikle uzaktan algılama ve coğrafi bilgi sistemlerinin kullanılmasıyla geniş alanlarda doğruluğu yüksek sonuçlar elde edilmektedir. Nitekim arazi kullanım planlamalarına temel oluşturan mevcut durumunun ve geçmişten günümüze değişimin tespit edilmesi sonucu karar vericiler için ileriye dönük projeksiyonların kurulması ile sürdürülebilir arazi kullanım planlamalarına önemli katkılar sağlamaktadır. Çalışma sonucu elde edilen güvenilir bulgular bu alanda uzaktan algilama ve CBS tekniklerinin sistematik sinıflama yöntemleri ile uyumlu bir şekilde kullanılabildiğini ve bu tekniklerin etkin arazi kullanım politikalarının geliştirilmesinde standart yaklaşımlar olarak kullanılabileceği önerilmiştir.

\section{Teşekkür}

$\mathrm{Bu}$ çalışma; T.C. Tarım ve Orman Bakanlığı, Tarımsal Araştırmalar ve Politikalar Genel Müdürlüğü (TAGEM) tarafından desteklenen TAGEM/TSKAD/B/18/A9/P2/1017 kodlu "Coğrafi Bilgi Sistem Modellemesi ile Tarımsal
Arazi Kullanım Planının Yapılması -Vezirköprü Örneği” projesi kapsamında üretilmiştir.

\section{Kaynaklar}

Anonim, 1984. Samsun İl Arazi varlığı. Köy Hizmetleri Genel Müdürlüğü, Ankara.

Anonim, 1987. Genel Toprak Amenajman Planlamas1. Köy Hizmetleri Genel Müdürlüğü, Ankara.

Anonim, 2020a. Bitkisel Üretim İstatistikleri. Türkiye İstatistik Kurumu (TÜİK), (http://www.tuik.gov.tr/ bitkiselapp/bitkisel.zulL, (Erişim tarihi: 20.04.2020).

Anonim, 2020b. Meteoroloji Genel Müdürlüğü Vezirköprü Bülteni. (https://www.mgm.gov.tr/veri degerlendirme/il-ve-ilçeleristatistikaspx?k=A\&m= SAMSUN), (Erişim tarihi: 15.03.2020).

Anonim, 2020c. Avrupa Cevre Ajans1, Corine 2000 Teknik Kilavuzu. (https://www.eea.europa.eu/tr), (Erişim tarihi: 20.04.2020).

Boyac1, D., 2012. CBS-uzaktan alg1lama entegrasyonu ve örnek uygulama: Uydu görüntülerinden detay ve otomatik Öznitelik tespiti. Doktora tezi, Selçuk Üniversitesi Fen Bilimleri Enstitüsü, Konya.

Bulut, H., Demirörs, Z., Alan, İ., Kaya, Ş., Bilgin, N., Öztaş, Z., Gürçayır, E., Darende, V., 2018. 2018 Yılı İzmir Meteorolojik Radar Verilerinin Zamansal ve CORINE Arazi Sınıflarına Göre Değişiminin Coğrafi Bilgi Sistemleri ile Analizi. Meteoroloji Genel Müdürlüğü Yazılım Geliştirme Şube Müdürlügüu, Ankara.

Çelik, H., 2006. İstanbul Sarıer ilçesine ait uzaktan algilama uydu verileri ile mekansal veri analizleri. Yüksek lisans tezi, Canakkale Onsekiz Mart Üniversitesi, Fen Bilimleri Enstitüsü, Çanakkale.

Demirbüken, H., 1996. Ankara ili yerleşim alanı arazi örtüsünün ve 1986-1995 yılları arasındaki değişimin uzaktan algılama teknikleri ile belirlenmesi. Bilim Uzmanlığ 1 Tezi, Hacettepe Üniversitesi, Fen Bilimleri Enstitüsü, Çevre Bilimleri Anabilim Dalı, Ankara.

Dengiz, O., Demirağ Turan, İ., 2014. Uzaktan algilama ve coğrafi bilgi sistem teknikleri kullanılarak arazi örtüsü/arazi kullanımı zamansal değişimin belirlenmesi: Samsun Merkez ilçesi örneği (19842011). Türkiye Tarımsal Araştırmalar Dergisi, 1(1): 78-90.

Dengiz, O., Demirağ Turan, İ., Özkan, B., 2019. Erzurum ili temel coğrafi özellikleri ve potansiyel işlemeli tarım alanı varlığı. Atatürk Üniversitesi Ziraat Fakültesi Dergisi, 50(2): 136-152.

Dengiz, O., Sarığlu, F.E., 2011. Samsun ilinin potansiyel tarım alanlarının genel dağılımları ve toprak etüt ve haritalama çalışmalarının önemi. Anadolu Tartm Bilimleri Dergisi, 26(3): 241-253.

Di Gregorio, A., Jansen, L.J.M., 2001. Land-Cover Classification System (LCCS): Classification Concepts and User Manual. FAO, Rome.

Ekercin, Semih., 2007. Uzaktan algılama ve coğrafi bilgi sistemleri entegrasyonu ile Tuz Gölü ve yakın çevresinin zamana bağlı değişimi. Doktora tezi, 
İstanbul Teknik Üniversitesi, Fen Bilimleri Enstitüsü, İstanbul.

Eryılmaz, Y., 2000. Uzaktan algilama metoduyla arazi kullanımının sınıflanması ve arazi kullanımında değişikliklerin tespiti (Çanakkale Örneği, 19921998). Yüksek lisans tezi, Gebze İleri Teknoloji Enstitüsü, Kocaeli.

Everest, T., Akbulak, C., Özcan, H., 2011. Arazi kullanım etkinliğinin değerlendirilmesi: Edirne ili Havsa ilçesi örneği. Anadolu Tarım Bilimleri Dergisi, 26(3): 251257.

Forkuor, G., Dimobe, K., Serme, I., Tondoh, J. E., 2018. Landsat-8 vs. Sentinel-2: Examining the added value of Sentinel-2's red-edge bands to land-use and landcover mapping in Burkina Faso. Giscience \& Remote Sensing, 55(3): 331-354.

Gençer, M., 2011. Eğirdir Gölünü çevreleyen arazilerin CORINE yöntemine göre arazi kullanım sınıflaması. Yüksek lisans tezi, Süleyman Demirel Üniversitesi Fen Bilimleri Enstitüsü, Isparta.

Gülersoy, A.E., 2014. Seferihisar'da arazi kullanımının zamansal değişimi (1984-2010) ve ideal arazi kullanımı için öneriler. Süleyman Demirel Üniversitesi, Fen Edebiyat Fakültesi Sosyal Bilimler Dergisi, 31(1): 155-180.

Hassan, Z., Shabbir, R., Ahmad, S.S., Malik, A.H., Aziz, N., Butt, A., Erum, S., 2016. Dynamics of land use and land cover change (LULCC) using geospatial techniques: a case study of Islamabad Pakistan. Springer Plus, 5(1): 812-913.

Karnieli, A., Rozenstein, O., 2011. Comparison of methods for land-use classification incorporating remote sensing and GIS inputs. Applied Geography, 31(2): 533-544.

Kaya, N., 2019. Bitki desenlerinin belirlenmesinde uzaktan algılamanın kullanılması. Yüksek lisans tezi, Ankara Üniversitesi Fen Bilimleri Enstitüsü, Ankara.

Keleş., B., Durduran, S.S., 2019. Osmaniye ilinin arazi örtüsü ve kullanımındaki zamansal değişimin uzaktan algılama teknikleri ile araştırılması. Necmettin Erbakan Üniversitesi Fen ve Mühendislik Bilimleri Dergisi, 1(1): 32-52.

Ketema, H., Wei, W., Legesse, A., Wolde, Z., Temesgen, H., Yimer, F., Mamo, A., 2020. Quantifying smallholder farmers'managed land use/landcover dynamics and its drivers in contrasting agroecologicalzones of the East African Rift. Global Ecology and Conservation, 21(1): 1-16.

Koç, A., Yener, H., 2001. Uzaktan algılama verileriyle İstanbul çevresi ormanlarının alansal ve yapısal değişikliklerinin saptanması. Ístanbul Üniversitesi, Orman Fakültesi Dergisi, Seri A, 51(2): 17-36.

Lillesand, T.M., Kiefer, R.W., Chipman, J.W., 2007. Remote Sensing and Image Interpretation. Sixth Edition, New York, USA: John Wiley \& Sons.
Lindsay, W.L., Norvell, W.A., 1978. Development of a DTPA soil test for zinc, iron, manganese and copper. Soil Science Society of American Journal, 42(3): 421428.

Newhall, F., Berdanier, C.R., 1996. Calculation of Soil Moisture Regimes from the Climatic Record. Soil Survey Investigations Report No. 46, National Soil Survey Center, Natural Resources Conservation Service, Lincoln, NE.

Özdemir, İ., Özkan, Y.U., 2003. Armutlu Orman İşletme Şefliğindeki orman alanlarındaki değişimin LANDSAT uydu görüntülerinin kullanılarak değerlendirilmesi. Süleyman Demirel Üniversitesi Orman Fakültesi Dergisi, 1: 55-66.

Öztürk, D., Gündüz, U., 2019. Samsun ili arazi kullanımı/örtüsünün mekânsal-zamansal değişimlerinin fraktal analiz kullanılarak belirlenmesi. Uludă̆ Üniversitesi Mühendislik Fakültesi Dergisi, 24(2): 643-660.

Öztürk, M., Mermut, A., Çelik, A., 2010. Land Degradation, Urbanisation, Land Use Environment. NAM Science \& Technology Centre.

Özyazıc1, M.A., Dengiz, O., İmamoğlu, A., 2014. Siirt ili bazı arazi ve toprak özelliklerinin coğrafi bilgi sistem analizleriyle değerlendirilmesi. Türkiye Tarımsal Araştırmalar Dergisi, 1(2): 128-137.

Sertel, E., Musaoğlu, N., Alp, G., Yay Algan, I., Kaya, Ş., Yüksel, B., Yılmaz, A., 2018. 1:25.000 ölçekli ulusal arazi örtüsü/kullanımı sinıflandırma sistemi ile HGK TOPOVT Veritabanının Karşılaştırılması. Harita Dergisi, 160(1): 34-46.

Şimşek, A., 2017. CORINE 4. seviye arazi örtüsü/kullanım sınıflarının belirlenmesi ve yüzey akış risk haritasının oluşturulması (Bartın Çayı Havzası örneği). Yüksek lisans tezi, Bartın Üniversitesi Fen Bilimleri Enstitüsü, Bartın.

Van Wambeke, A., Hastings, P., Tolomeo, M., 1986. Newhall Simulation Model: A BASIC Program for The IBM PC. Department of Agronomy, Cornell University. Diskette and Booklet. Ithaca, NY. Washington, DC.

Van Wambeke, A., Hastings, P., Tolomeo, M., 1992. Newhall Simulation Model-A BASIC Program for the IBM PC (DOS 2.0orlater). Cornell University, Department of Agronomy, Ithaca, NY. Washington, DC.

Van Wambeke, A.R., 2000. The Newhall Simulation Model for Estimating Soil Moisture \& Temperature Regimes. Department of Crop and Soil Sciences, U.S. Departmanet of Agriculture, Ithaca, N.Y. Washington, DC.

Yan, G., Mas, J.F., Maathuis, B.H., Xiangmin, Z., Van Dijk, P. M., 2006. Comparison of Pixelbased and Object-Oriented Image Classification Approaches-A Case Study in a Coal Fire Area, Wuda, Inner Mongolia, China. 